\title{
An Update on the Histology of Pheochromocytomas: How Does it Relate to Genetics?
}

Authors

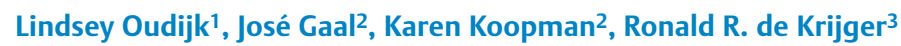

\author{
Affiliations \\ 1 Department of Pathology, Erasmus MC University \\ Medical Center, Rotterdam, The Netherlands \\ 2 Department of Pathology, Isala Clinics, Zwolle, The \\ Netherlands \\ 3 Department of Pathology, University Medical Center/ \\ Princess Maxima Center for Pediatric Oncology, Utrecht \\ and Reinier de Graaf Hospital, Delft, The Netherlands
}

\author{
Key words \\ pheochromocytoma, histology, genetics \\ received $\quad 17.05 .2018$ \\ accepted $\quad 02.08 .2018$

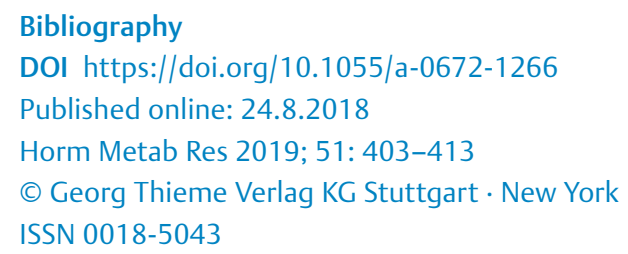

\author{
Postbus 2040 \\ Rotterdam 3000 CA \\ Rotterdam \\ The Netherlands \\ Tel.: + 31/107/044 396, Fax: + 31/107/044 762 \\ l.oudijk@erasmusmc.nl
}

\section{ABSTRACT}

Pheochromocytomas are rare neuroendocrine tumors of the adrenal gland, whereas any extra-adrenal tumor with similar histology is designated as paraganglioma. These tumors have a very high rate of germline mutations in a large number of genes, up to $35 \%$ to $40 \%$, frequently predisposing for other tumors as well. Therefore, they represent a phenomenal challenge for treating physicians. This review focuses on pheochromocytomas only, with special attention to gross and microscopic clues to the diagnosis of genetic syndromes, including the role of succinate dehydrogenase subunit $A$ and subunit $B$ immunohistochemistry as surrogate markers for genetic analysis in the field of succinate dehydrogenase subunit gene mutations.

\section{Introduction}

Pheochromocytomas (PCC) and paragangliomas (PGL) are rare tumors, originating from neural crest-derived precursor cells, that occur in the adrenal gland and in sympathetic and parasympathetic ganglia in the abdomen, thorax, pelvis, and head and neck area, respectively. Histologically, they are very similar and frequently indistinguishable, although PCC tend to have more nuclear atypia and cytoplasmic basophilia, whereas PGL display less atypia and are usually more eosinophilic. Their histopathological recognition is usually straightforward and in equivocal cases the neuroendocrine markers synaptophysin and chromogranin A can be used, both of which should show diffuse strong cytoplasmic staining. In addition, the use of S100 may be supportive when showing a sustentacular cell pattern of non-neoplastic cells that surround the nodules of PCC tumor cells, the so-called "Zellballen" ( $\triangleright$ Fig. 1).

Over the past decades, it has been shown that these tumors carry a very high rate of germline mutations, up to $35 \%$ to $40 \%$ in some series, making them one of the most heritable tumor types in the body, necessitating clinical genetic counseling and germline mutation analysis in every patient [1,2]. The number of genes with germline mutations leading to PCC and PGL has increased to almost 20 , although for some genes only few families or index patients have been described. While we are entering the era of genome-wide mutation analysis at ever decreasing cost, currently such an approach is not the state of the art in most settings, even in developed countries. Therefore, a stepwise approach, guided by clinical and histopathological information is currently still preferred. This review article describes the various (groups of) germline mutations and the contribution of gross analysis of adrenalectomy specimens, histopathology on the basis of hematoxylin and eosin (HE)-stained sections, and immunohistochemistry to the elucidation of a potential hereditary background of PCC and PGL. 


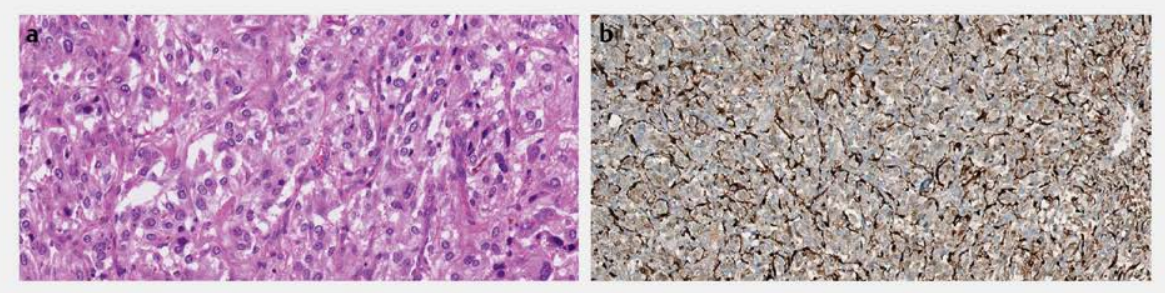

- Fig. 1 a: Hematoxylin and eosin (H \& E) staining of PCC with nested growth pattern. b: S100 immunostaining showing typical sustentacular cell pattern around the cell nests.

\section{Multiple Endocrine Neoplasia Type 2}

Multiple endocrine neoplasia type 2 (MEN2) was first described in 1961. It is a rare autosomal dominant syndrome caused by mutations in the RET proto-oncogene. This gene is located on chromosome 10q11.2 and encodes a transmembrane tyrosine kinase enzyme. When ligand binds to the RET receptor, or if there is an activating mutation, a cell signaling cascade is triggered through the PI3 kinase pathway to regulate cell proliferation and apoptosis [3-5].

MEN2A is the most common subtype of MEN2 and comprises medullary thyroid carcinoma, PCC, and primary hyperparathyroidism. MEN2B is characterized by medullary thyroid cancer, PCC, a Marfanoid habitus, and mucosal ganglioneuromas. PCC occur in 40-50\% of patients with MEN2, are usually detected between 30 and 40 years of age, and are the presenting tumor in up to $25 \%$ of MEN2 patients. The risk of PCC is associated with specific RET mutations [3,6]. The rate of metastatic PCC is less than $5 \%$ [7]. Clues to a MEN2-related PCC are multiple and bilateral tumor nodules and the presence of adrenal medullary hyperplasia (AMH). In addition, AMH and PCC show identical molecular alterations. This suggests that $\mathrm{AMH}$ does not represent a physiologic increase of adrenomedullary cells, but should be regarded as a precursor lesion of PCC or as a small PCC [8-10]. Individual PCC can differ from each other both architecturally and cytologically. Hyaline globules are often abundant in MEN2 [11].

\section{Von Hippel-Lindau}

Von Hippel-Lindau (VHL) is an autosomal dominant familial tumor syndrome characterized by multiple benign and malignant tumors including retinal and central nervous system hemangioblastomas, renal cysts and renal clear cell carcinomas, pancreatic cysts and pancreatic neuroendocrine tumors, endolymphatic sac tumors, and epididymal cystadenomas [1]. VHL is categorized into two major types depending on the absence (type 1) or presence of PCC (type 2). Germline mutations in the VHL tumor suppressor gene at chromosome 3p25 in combination with a second hit with loss of the wild type allele result in tumorigenesis. The $\mathrm{VHL}$ gene encodes two proteins (pVHL30 and pVHL19). pVHL plays a critical role in regulating the degradation of hypoxia inducible factor (HIF)1 alpha and HIF2alpha. HIFs can activate genes that participate in cellular adaptation and growth under hypoxic conditions. Under normal conditions, $\mathrm{pVHL}$ can bind to the $\alpha$ subunits of the transcription factors HIF1 and
HIF2 and targets them for ubiquitination and proteosomal degradation. Under hypoxic conditions or pVHL dysfunction, HIFs are stabilized and activate target genes inducing angiogenesis, metabolism, apoptosis, and proliferation [12]. Type $1 \mathrm{VHL}$ is usually associated with non-functional protein mutations, whereas in type $2 \mathrm{VHL}$ mutations encode a protein with some activity $[4,12]$.

PCC are observed in $10-26 \%$ of VHL patients, with a mean age of presentation of 30 years and PCC can be the first clinical symptom in one third of the patients. The metastatic rate is $5 \%[4,12]$. VHL-related PCC are often bilateral and/or multifocal, but in contrast to MEN2 there is no AMH. Other distinctive features of PCC in VHL are a thick vascular tumor capsule, myxoid stroma, small to medium sized tumor cells with prominent amphophilic and/or clear cytoplasm, intermingling of small vessels, absence of hyaline globules, and lack of nuclear atypia or mitosis [13]. It has been suggested that membranous carbonic anhydrase IX expression (a hypoxia marker) may be a potential immunohistochemical marker for VHL-related PCC, but further validation is required [14].

\section{Neurofibromatosis Type 1}

Neurofibromatosis type 1 (NF1), an autosomal dominant disorder, is caused by inactivating mutations in the NF1 gene, located on chromosome 17q11.2. This gene encodes neurofibromin 1, which is a negative regulator of the RAS intracellular signaling pathway. The syndrome is characterized by multiple neurofibromas, café au lait spots, axillary and inguinal freckling, Lisch nodules of the iris, optic nerve gliomas, dysplasia of the long bones, peripheral nerve sheath tumors, gastrointestinal stromal tumors (GIST), pancreatic neuroendocrine tumors, leukemia, and PCC. The diagnosis is based on clinical diagnostic criteria rather than genetic testing since the gene is large and there is no hotspot for mutations [15]. Less than $6 \%$ of NF1 patients develop PCC with a mean age of presentation of 42 years. Bilateral tumors are seen in $25 \%$ of these patients. The metastatic rate is $12 \%$ [3]. Up to $16 \%$ of PCC in NF1 show a composite phenotype of PCC intermixed with areas of ganglioneuroblastoma or ganglioneuroma [16]. Immunohistochemical NF1 staining does not predict NF1 gene mutation status in PCC [17]. 


\section{Succinate Dehydrogenase Enzyme-related Genes}

Germline mutations in one of the succinate dehydrogenase (SDH) genes are the most frequent cause of hereditary PCC/PGL and account for nearly $50 \%$ of mutations in these tumors [10]. The SDH complex is a key respiratory enzyme for normal aerobic respiration located at the inner mitochondrial membrane [18]. The complex is composed of the four subunits SDHA, SDHB, SDHC, and SDHD, each encoded by corresponding genes on the autosomal DNA [18]. Succinate dehydrogenase assembly factor 2 (SDHAF2) is needed for the flavination and correct functioning of SDHA [19]. If any of the SDH components is lost due to (epi)mutation, the entire complex becomes instable and the SDHB subunit is degraded in the cytoplasm [18]. The consequent loss of SDHB protein expression can be detected by the use of immunohistochemistry for the SDHB protein [20]. Tumors with inactivation of SDHA, SDHB, SDHC, SDHD, or SDHAF2 do not show specific gross or microscopic characteristics that distinguish them from other PCC. However, they demonstrate loss of cytoplasmic SDHB staining ( $>$ Fig. 2). Of note, double-hit inactivation of one of the SDH genes almost always occurs as a result of germline mutations, together with loss of the other allele, instead of somatic changes [21]. So, SDHB immunohistochemistry can be used as a quick and cheap marker for syndromic SDH deficient tumors.

In addition, SDHA immunohistochemistry can be used to detect tumors with germline SDHA mutations, as SDHA staining becomes negative in SDHA-mutated tumors, while tumors with SDHB, SDHC, SDHD, or SDHAF2 mutations retain SDHA staining [22]. SDHD immunostaining has been described as an adjunct in cases with difficult to interpret SDHB staining due to nonspecific back- ground [23], as SDHD immunostaining is positive in SDH-mutated cases. However, this has not been validated in other studies.

Interpretation of SDHB immunohistochemistry has its pitfalls [24]. To start with, it is very important that an intrinsic positive control is identified in non-tumoral cells, that is, endothelial cells, fibroblasts or immune cells. Then, one should look at the pattern and intensity of staining: normal (mitochondrial) positive staining is strongly granular and cytoplasmic. When the cytoplasmic staining of the tumor cells is clearly less intense compared to the staining of the endothelial cells, SDHB should be considered negative. Also, when there is a weak diffuse cytoplasmic blush instead of a strong granular pattern, SDHB should be regarded as negative ( $\triangleright$ Fig. 2d). The latter scenario is more likely to occur in SDHD-mutated tumors [23]. Also, caution should be taken when interpreting SDHB immunohistochemistry in tumor areas with clear cytoplasm, as staining might occur negative. The best approach is to look for (focal) areas with eosinophilic cytoplasm to interpret the staining [25].

Syndromic PCC/PGL with germline SDH mutations show clinicopathological associations that must be borne in mind by both clinicians and pathologists. In short, SDHB-mutated tumors are mainly extra-adrenal sympathetic $P G L$ and are associated with a high risk of metastasis [26-28]. Germline SDHD mutations predispose most frequently to multiple non-metastatic head and neck PGL [28]. SDHC mutations are rare and are mainly associated with carotid body PGL [28]. Both SDHD and SDHAF2 are maternally imprinted and disease only develops after paternal transmission $[29,30]$. SDHA mutations are extremely rare and display a reduced penetrance [31]. Most importantly, there are newly recognized SDH-associated tumors, such as GIST, renal cell carcinomas (RCC) and pituitary adenomas (PA), which will briefly be discussed hereafter.

SDH-deficient GIST show distinct clinical, morphological and immunohistochemical features which separate them from other
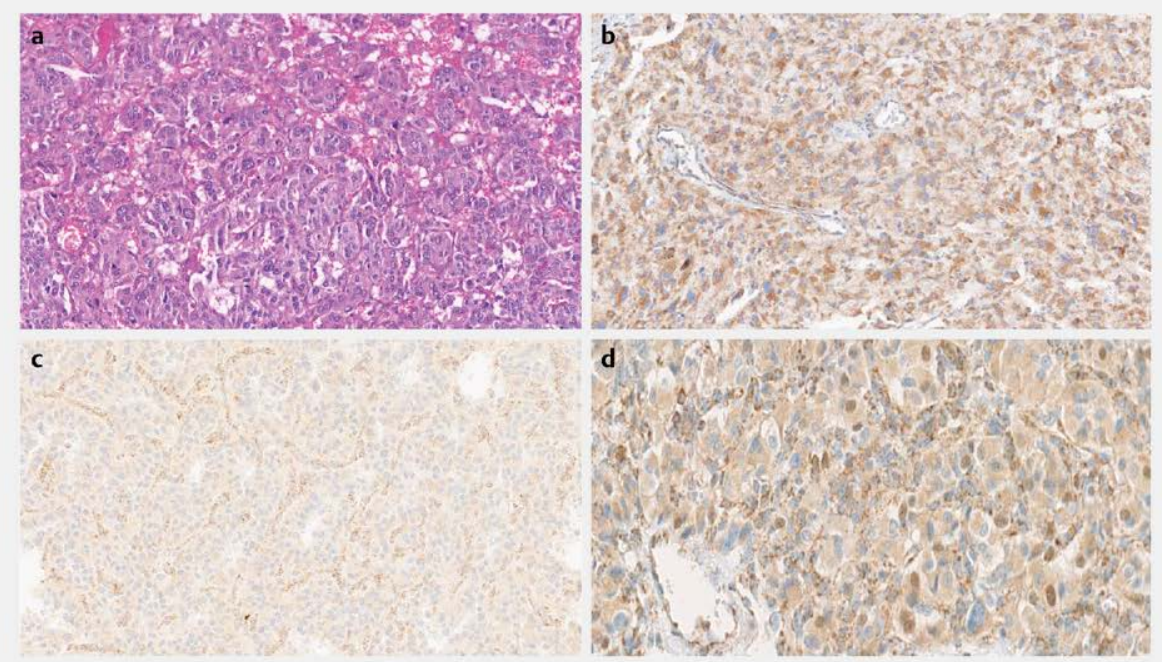

- Fig. 2 a: H \& E staining showing PCC composed of tumor cell nests (Zellballen) separated by a rich vascular plexus and sustentacular cells. b: positive SDHB immunostaining in a non-SDH-related PCC showing granular cytoplasmic staining in both tumor and endothelial cells. c: Negative SDHB immunostaining in an SDH-mutated PCC showing tumor cells with absent SDHB staining. Immunoreactivity for the SDHB protein is present in endothelial cells, which serve as internal positive controls. d: False positive (diffuse) cytoplasmic SDHB staining in an SDHD-mutated PGL. Note the contrast of the more intense dark brown and granular staining in the endothelial cells. 


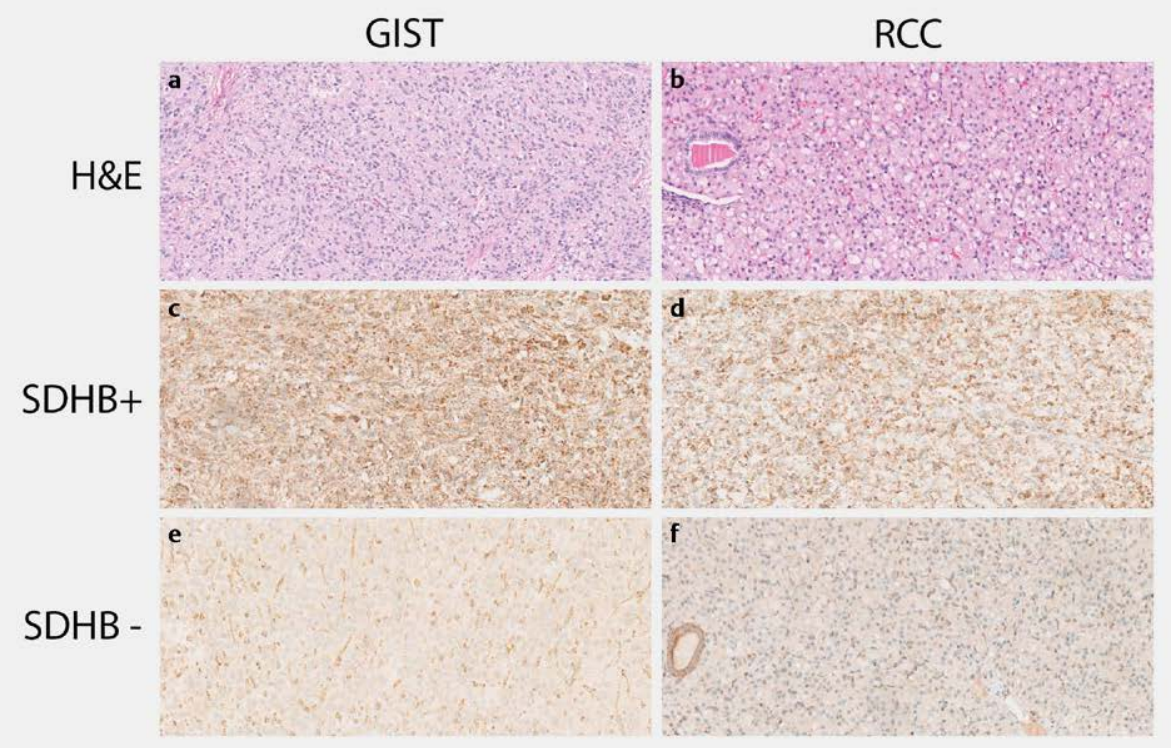

- Fig. 3 a: H \& E stain of an SDHA-mutated GIST composed of epithelioid tumor cells. b: H\&E stain of an SDH-deficient RCC with typical cytoplasmic vacuoles. Note the entrapped non-neoplastic tubule on the left. c, d: positive SDHB immunostains in a non-SDH-related GIST (C) and in a clear cell RCC (D). e, f: Negative SDHB immunostains in an SDH-mutated GIST (E) and in an SDH-deficient RCC (F).

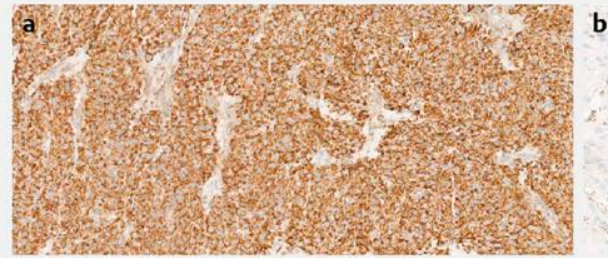

- Fig. 4 a: Positive granular cytoplasmic SDHA staining in a non-SDH-mutated GIST. b: Absence of SDHA staining in the tumor cells of an SDHA-mutated GIST (B). Again, endothelial cells serve as internal positive control.

GIST [32]. This class of GIST shows a female predominance and lymph node metastases are common, but the clinical course is usually indolent. The tumors arise in the stomach, are commonly multi-focal and demonstrate a multi-nodular, lobulated growth pattern composed of predominantly epithelioid cells ( $\bullet$ Fig. 3 ) [25]. SDH-deficient GIST are always negative for SDHB and strongly positive for both KIT and DOG1 by immunohistochemistry [32,33]. Genetically, about $30 \%$ of SDH-deficient GIST are associated with SDHA mutations, which can be identified by loss of immunohistochemical SDHA protein expression ( $\triangleright$ Fig. 4) [34]. Up to $20 \%$ of tumors are associated with SDHB, SDHC or SDHD mutations and the remaining $50 \%$ harbors epigenetic hypermethylation of the SDHC promoter [25]. Mutations in SDHB, SDHC, and SDHD can also give rise to Carney-Stratakis syndrome, the familial dyad of PGL and GIST $[35,36]$. The non-familial Carney triad is associated with SDH-deficient GIST, PGL and pulmonary chondromas and shows hypermethylation of the SDHC promotor $[36,37]$.

SDH-deficient RCC is currently being recognized as a distinct type of RCC in the WHO 2016 classification [25]. This class of RCC has a low risk of metastasis and demonstrates characteristic mor- phological features: 1) cystic change is common; 2) the tumor cells display eosinophilic cytoplasm with typical cytoplasmic vacuoles or inclusions, but lack the cytoplasmic granularity of oncocytes; 3 ) the nuclei are homogeneous with a neuroendocrine appearance; 4) non-neoplastic tubules or glomeruli are frequently entrapped at the periphery of the tumor ( $\vee$ Fig. 3 ). Mast cells can be identified in the intratumoral stroma [38]. Most reported SDH-deficient RCC have been associated with SDHB mutation carriers, in which the risk of RCC by age 60 years is $4.7 \%$ [27]. However, RCC can occur in SDHC and SDHD mutation carriers as well, and one case of SDHA-deficient RCC has been described [39, 40].

SDH-deficient pituitary adenomas are very rare and to date, about 25 cases have been described in association with SDHA, SDHB, SDHC, and SDHD mutations [41]. These tumors are most often prolactin-producing or, to a lesser extent growth hormone-producing macroadenomas, but no distinct morphologic features have been reported $[25,41]$. 


\section{MYC-Associated Factor X}

MYC-associated factor X (MAX) mutations were found to be a cause of hereditary PCC in 2011 [42]. A later study identified somatic MAX mutations, in addition to germline MAX mutations [43]. Patients with MAX mutations presented with bilateral and multiple PCC within the same adrenal gland.

MAX germline mutations have also been described in renal tumors. One case with a large genomic alteration in MAX was found in a patient with renal oncocytoma, erythrocytosis and bilateral PCC [44]. Initial data suggest that pathogenic variants in MAX exhibit parent-of-origin effects similar to those of pathogenic variants in SDHD where disease only becomes apparent when the pathogenic variant is inherited from the father.

Besides the multiple ipsilateral tumors there are no particular histologic characteristics described for MAX-mutated PCC and PGL. Immunohistochemical detection of MAX in tumor-embedded paraffin slides showed complete loss of the protein in all analyzed tumors that carried truncating mutations. Positive immunohistochemical staining was observed in all non-truncating variants. Some of these genetic variants were considered variants of unknown significance (VUS) [43]. Others have described that many PCC/PGL not associated with MAX mutations also demonstrate loss of MAX expression by immunohistochemistry, and that several PCC/PGL associated with MAX mutations do not demonstrate MAX loss by immunohistochemistry [45]. Therefore, MAX immunohistochemistry needs to be studied in larger series than hitherto performed.

\section{Fumarate Hydratase}

Fumarate hydratase (FH) is encoded by the $\mathrm{FH}$ gene on chromosome 1q42.1. Inactivation of this tricarboxylic acid cycle enzyme leads to abnormal cellular activation of the hypoxic gene response pathway and DNA methylation. Classically, FH mutations are associated with hereditary cutaneous and uterine leiomyomatosis and RCC [46]. In 2013, five patients with PCC/PGL were identified carrying FH mutations. Three of these five patients had metastatic PCC/PGL $[47,48]$. In addition a FH germline mutation was found in a pediatric PCC [49]. No particular histologic characteristics have been described. However, the accumulation of $\mathrm{FH}$ in these tumors leads to protein succination, which can be revealed by $2 \mathrm{SC}$ immunostaining. In addition, the accumulation of fumarate causes an inhibition of DNA methylases of the TET family involved in the hydroxylation of 5-methylcytosine to generate 5 -hmC. FH-deficient tumors show (similar to SDHB-deficient tumors) an altered immunostaining pattern for 5-hmC. Immunohistochemical staining for 5-hmC is strongly positive in RET- and NF1-mutated tumors, and is negative in SDHB- and $\mathrm{FH}$-mutated tumors (with positive internal control of endothelial cells) [48]. In addition to distinct loss of $5 \mathrm{hmC}$ in tumor cells in SDHand $\mathrm{FH}$-deficient tumors, it has been shown that FH-deficient smooth muscle tumors exhibit increased $\mathrm{H} 3 \mathrm{~K} 9 \mathrm{me} 3$ methylation compared to wildtype tumors [50]. FH immunohistochemistry using the same criteria as for interpretation of SDHB immunohistochemistry can be used. One group has identified several germline FH-mutated PCC and one somatic FH-mutated PCC with loss of expression of FH by immunohistochemistry [45].

\section{Transmembrane Protein 127}

The TMEM127 tumor suppressor gene encodes a transmembrane protein that functions as a negative regulator of the mTOR pathway. Germline mutations in this gene were found in familial and sporadic PCC and a few cases have been described harboring PGL $[51,52]$. The prevalence of PCC seems low (2-4\%). Clinically, patients are characterized by frequent bilateral PCC and a relatively high mean age at diagnosis compared to other syndromic PCC/PGL. The mean age at development of TMEM127-mutated tumors is 42.8 years and the median is 41.5 years. This age at onset is similar to the age of non-mutated cases (mean 43.2 years and median 45 years). This is in contrast with patients with hereditary PCC due to mutations in other susceptibility genes, in whom the disease has an earlier manifestation [53]. Metastases are detected in only a few cases, and no somatic TMEM127 mutations have yet been described. There are no particular histologic characteristics.

\section{Prolyl Hydroxylase 1 and 2}

Prolyl hydroxylase domain (PHD) proteins are involved in the degradation of HIF by hydroxylation. There are three main isoforms: PHD1, PHD2, and PHD3. Mutations in PHD2 have been implicated in the pathogenesis of polycythemia. However, recently germline PHD1 and PHD2 mutations have been described in patients with multiple PCC/PGL and polycythemia [54, 55]. Immunohistochemical expression of PHD1 and PHD2 proteins in tumors with PHD1 and PHD2 mutations was compared to normal adrenal medulla and to a sporadic non-PHD1/2-mutated PCC. The PHD1-related tumor showed negative staining for PHD1, while the expression of PHD2 was heterogeneous, with areas of negative staining (0) and areas with weak $(1+)$ staining. PHD1 expression in the PHD2-mutated tumor was scored 1-2+; PHD2 staining in this sample was weak $(1+)$. In the sporadic PCC, PHD1 staining exhibited intermediate/ strong $(2-3+)$ intensity and PHD2 staining was scored 1-2+. Human adrenal medulla shows strong $(3+)$ staining for PHD1 and intermediate $(2+)$ staining for PHD2 [55]. Although it appears that there might be a role for PHD1 and PHD2 immunohistochemistry in selected cases, this may not be practical given the small number of cases that has been described so far, both with regard to PHD mutations, and with regard to immunohistochemistry.

\section{Hypoxia Inducible Factor 2 Alpha}

HIF2alpha, encoded by EPAS1/HIF2A located on chromosome 2p21, is a transcription factor that responds to oxygen concentrations in tissue. It is a subunit of a heterodimer of which the other component is aryl hydrocarbon receptor nuclear translocator 2 (ARNT2/HIF2B). Under hypoxic conditions HIF stabilizes, thereby activating the hypoxia signaling pathway leading to angiogenesis, erythropoiesis, and cell growth [56]. In 2012, somatic HIF2A mutations were described in two patients with polycythemia and multiple PGL. One of these patients had a duodenal somatostatinoma [57]. Favier et al. found a heterozygous mutation in a PCC which affected the prolyl hydroxylase target residue of HIF2A. Gene expression data showed increased expression of hypoxia inducible genes. However, the effect was milder than seen in tumors with mutations in SDHx or VHL[58]. In 2013, 
four additional unrelated patients with somatic HIF2A mutations with multiple PGL, somatostatinomas and polycythemia were described, indicating a new syndrome [59]. In addition, germline mutations have been identified [60,61]. It is now known that HIF2A mutations are identified in a variety of phenotypes, including polycythemia without tumors, polycythemia with single or multiple PCC/ PGL, with and without somatostatinomas [56, 57, 60-63]. In addition, single or multiple PCC and PGL without polycythemia may occur $[64,65]$. The fact that somatic mutations were found in patients with multiple PGL, somatostatinomas and polycythemia suggests the occurrence of a de novo postzygotic HIF2A mutation. In one patient it was shown that a heterozygous HIF2A mutation was present in the $\mathrm{PGL}$, and that this mutation was also present as a mosaic in leukocyte DNA [66].

No specific macroscopic appearance or histologic features have been described for the PCC/PGL. In one study, immunohistochemistry for HIF1alpha and HIF2alpha was performed on the somatostatinoma and PGL of one HIF2A-mutated patient. Tumor cells showed nuclear staining for HIF2alpha in contrast to HIF1alpha where there was no nuclear staining [59]. Given the low number of cases, further analysis is needed to find out if there is role for $\mathrm{HI}$ F1alpha and HIF2alpha immunohistochemistry in the detection of specific subgroups of PCC.

\section{Kinesin Family Member 1B}

The Kinesin Family member 1B (KIF1B) gene is located on chromosome 1p36.22 and encodes for protein kinesin family member 1B. There are two isoforms, KIF1Balpha and KIF1Bbeta. These proteins are responsible for transport of materials via microtubules within cells and are abundantly expressed in differentiated nerve cells [67]. Studies suggest that deletion or mutation of the KIF1B gene may disrupt apoptosis, which leads to tumorigenesis. KIF1B mutations have been described in neuroblastomas and in Charcot-Marie-Tooth disease type $2 A$ peripheral neuropathy $[68,69]$. In 2008 the first PCC cases with KIF1B germline mutations were published. In this study, all 46 exons of KIF1Bbeta were sequenced and a missense variant was found in 2/52 PCC [70]. Evenepoel et al. sequenced 74 tumors (47 PCC and 27 PGL) and identified somatic mutations in $54 \%$ of patients. In this study, the most frequently somatically mutated genes in PCC were NF1 (20.8\%) and KIF1B (20.4\%). No significant difference in the proportion of KIF1B mutations was observed between PCC and PGL (46\% vs. 30\%) [71]. Yeh et al. described germline KIF1Bbeta mutations in a family with neural and non-neural tumors. One female patient presented at 17 months of age with a neuroblastoma and developed a ganglioneuroma and bilateral PCC. Her paternal grandfather also developed bilateral PCC, which showed few areas of necrosis, diffuse architecture and hyaline globules, narrowed cord pattern, anisokaryosis and intense adjacent medullary hyperplasia [70,72]. The patient's PCC also showed narrowed cord pattern, hyaline globules and in some areas atypia/anisokaryotic cells. In addition, an intracapillary tumor embolus was present. FISH analysis of the tumors showed two signals for KIF1Bbeta and no LOH was identified by SNP array. These findings deviate from the classic two-hit tumor suppressor gene model.

\section{Multiple Endocrine Neoplasia Type 1}

Multiple endocrine neoplasia type 1 (MEN1) is characterized by tumors of the parathyroid, pancreas and pituitary. In addition, some patients may develop bronchial carcinoids, facial angiofibromas, and adrenal cortical tumors. MEN1 is a tumor suppressor gene located on chromosome 11q13.1 and encodes for the protein menin. This protein is present in the nucleus of many different types of cells and interacts with transcription factor JunD [73]. No clear genotype-phenotype correlation is present. Adrenal involvement in MEN1 is about $20 \%$ and almost exclusively concerns adrenal cortical lesions [74]. PCC in MEN1 are rare; only a few cases have been described [75]. Most tumors are unilateral and metastasis has only been described in one patient [76]. Okada et al. described an MEN1-patient with a giant insulinoma of the pancreatic tail, concomitant PCC and an adrenal cortical adenoma in the same adrenal gland [77]. The combination of pituitary adenomas and PCC is rare and this has been associated with mutations in SDHA, SDHB, and SDHD $[78,79]$. Only four cases of co-existing PCC/PGL and pituitary adenoma have been reported in patients with MEN1. In one of these PCC absent menin staining was demonstrated [80]. In cell lines tested, menin was found both in the nucleus and in the cytoplasm, but its localization was dependent on the phase of the cell cycle; during a non-dividing phase, menin was found in the nucleus; during and immediately after cell division, it was found in the cytoplasm [81]. Tissue from MEN1-associated primary hyperparathyroidism was evaluated by immunohistochemistry. Lack of nuclear menin was identified in all MEN1-associated parathyroid tissues. The sensitivity and specificity of menin immunohistochemistry to detect a MEN1 mutation in this study were $86 \%$ and $87 \%$, respectively [82]. To the best of our knowledge, no results of menin immunohistochemistry on PCC/PGL have been reported.

\section{Recently Identified PCC/PGL Genes}

Malate dehydrogenase $2(\mathrm{MDH} 2)$ was identified as a familial PGL gene by whole-exome sequencing in a male patient with multiple retroperitoneal and thoracic PGL. MDH2 encodes another Krebs cycle enzyme, and malfunction results in a severe energy deficit and accumulation of malate and fumarate. A similar mechanism occurs in Fh1-deficient cells that accumulate fumarate (see above). Immunohistochemical staining of 5-hmC was undetectable in MDH2- and SDHB-mutated tumor cells, and was observed only in sustentacular and some stromal cells [83]. Very recently, it was shown that $\mathrm{MDH} 2$ might play a role in less than $1 \%$ of $\mathrm{PCC}$ and $\mathrm{PGL}$ that do not show mutations in other driver genes [84].

Targeted exome sequencing identified a germline glutamic-oxaloacetic transaminase 2 (GOT2) variant (c.357 A>T) in a patient with metastatic thoracic-abdominal PGL. GOT2 is a mitochondrial enzyme involved in amino acid metabolism and both the urea and Krebs cycle. In GOT2 -mutated (c.357A>T) tumor cells increased GOT2 expression and enzymatic activity was found, as well as a high succinate/fumarate ratio. GOT2 immunohistochemistry on two tumors of the patient showed cytoplasmic aggregates, while this was not observed in a control (non-GOT2 mutated) tumor [85]. In addition, a truncating germline IDH3B mutation was found in a 51-year-old patient with a jugular PGL. The beta subunit of isoc- 
- Table 1 Genes and tumor associations of pheochromocytoma (PCC) and paraganglioma (PGL).

\begin{tabular}{|c|c|c|c|c|c|}
\hline Gene & Site & $\begin{array}{l}\text { PCC/PGL } \\
\text { incidence }\end{array}$ & Other tumors & Clues for diagnosis & IHC PCC/PGL \\
\hline RET & $P C C » P G L$ & $40-50 \%$ & $\begin{array}{l}\text { MTC, parathyroid tumor, mucosal } \\
\text { ganglioneuroma }\end{array}$ & $\begin{array}{l}\text { Multiple and bilateral } \\
\text { tumors, } \mathrm{AMH}\end{array}$ & \\
\hline VHL & $P C C » P G L$ & $10-26 \%$ & $\begin{array}{l}\text { Clear cell RCC, hemangioblastoma, } \\
\text { retinal angioma, pancreatic serous } \\
\text { cystadenoma }\end{array}$ & $\begin{array}{l}\text { Multifocal and } \\
\text { bilateral tumors, } \\
\text { thick vascular tumor } \\
\text { capsule }\end{array}$ & CAIX + (?) \\
\hline NF1 & $P C C » P G L$ & $<6 \%$ & $\begin{array}{l}\text { Neurofibroma, ganglioneuroma, MPNST, } \\
\text { schwannoma, optic nerve glioma, GIST }\end{array}$ & $\begin{array}{l}\text { Composite PCC } \\
\text { intermixed with } \\
\text { ganglioneuroblasto- } \\
\text { ma/ganglioneuroma }\end{array}$ & \\
\hline SDHA & $\mathrm{PGL}>\mathrm{PCC}$ & Rare & SDH-def. GIST and RCC, PA & & SDHB - , SDHA - \\
\hline$S D H B$ & $\begin{array}{l}E A P G L » H \& N \\
P G L>P C C\end{array}$ & $25-40 \%$ & SDH-def. GIST and RCC, PA & & SDHB - , SDHA + \\
\hline$S D H C$ & $\begin{array}{l}\mathrm{H} \& N \text { PGL »EA } \\
\mathrm{PGL/PCC}\end{array}$ & Rare & SDH-def. GIST and RCC & & SDHB - , SDHA + \\
\hline$S D H D$ & $\begin{array}{l}\mathrm{H} \& N \text { PGL }>E A \\
P G L / P C C\end{array}$ & $86 \%$ & SDH-def. GIST and RCC, PA & & SDHB - , SDHA + \\
\hline SDHAF2 & $H \& N P G L$ & Very rare & Not reported & & SDHB - , SDHA + \\
\hline MAX & $P C C » P G L$ & Rare & Renal tumors, neuroblastoma & $\begin{array}{l}\text { Multiple and bilateral } \\
\text { tumors, } \mathrm{AMH}\end{array}$ & MAX - \\
\hline$F H$ & $\mathrm{PCC}$ and $\mathrm{PGL}$ & Rare & RCC, leiomyoma & & $2 \mathrm{SC}+, 5-\mathrm{hmC}-$ \\
\hline TMEM127 & PCC »PGL & $<20 \%$ & Not reported & & \\
\hline PHD1/2 & $\mathrm{PCC}$ and PGL & Rare & Not reported & & \\
\hline HIF2A & $P G L>P C C$ & Rare & Somatostatinoma & & HIF2a,+ HIF1a $-(?)$ \\
\hline KIF1B & PCC & Rare & $\begin{array}{l}\text { Ganglioneuroma, leiomyosarcoma, } \\
\text { neuroblastoma }\end{array}$ & & \\
\hline MEN1 & $P C C » P G L$ & Very rare & $\begin{array}{l}\text { Parathyroid tumors, enteropancreatic } \\
\text { NET, PA, thymus or bronchial carcinoid, } \\
\text { adrenal cortical tumors }\end{array}$ & & $\begin{array}{l}\text { Menin - in MEN1-associ- } \\
\text { ated parathyroid tissue }\end{array}$ \\
\hline $\mathrm{MDH} 2$ & PGL & Very rare & Neuroblastoma & & 5-hmC - \\
\hline GOT2 & PGL & Very rare & & & GOT2 + \\
\hline IDH3B & $H \& N P G L$ & Very rare & $\mathrm{AML}$ & & 5-hmC - \\
\hline SLC25A11 & PGL & $1 \%$ & & & $\begin{array}{l}\text { 5-hmC -, H3K9me3 +, } \\
\text { H3K27me3 +, OGC - }\end{array}$ \\
\hline DNMT3A & H \& N PGL & Very rare & AML & & H3K9me3 + \\
\hline
\end{tabular}

IHC: Immunohistochemistry; EA: Extra-adrenal; H \& N: Head and neck; MTC: Medullary thyroid carcinoma; RCC: Renal cell carcinoma; MPNST: Malignant peripheral nerve sheath tumor; GIST: Gastrointestinal stromal tumor; PA: Pituitary adenoma; SDH-def.: Succinate dehydrogenase-deficient; NET: Neuroendocrine tumor; AMH: Adrenal medullary hyperplasia; AML: Acute myelogenous leukemia; +: Positive staining; -: Negative staining.

itrate dehydrogenase $3(\mathrm{IDH} 3)$ is involved in the oxidation of isocitrate to $\alpha$-ketoglutarate in the Krebs cycle. The IDH3B-mutated PGL showed negative 5-hmC immunohistochemical staining, which is also found in $\mathrm{SDH}$ - and FH-mutated tumors [84].

A germline mutation in the SLC25A11 gene, which encodes the mitochondrial 2-oxoglutarate/malate carrier (OGC) was identified by whole-exome sequencing in an abdominal PGL in a 46-year-old male patient. In addition, six patients with germline SCL25A11 mutations were identified by Sanger sequencing in a large cohort of 639 patients (five patients with a single metastatic abdominal PGL and one with a head and neck PGL). SLC25A11 gene mutations ac- count for $1 \%$ of all PCC/PGL and confer a predisposition to metastatic tumors. No OGC protein was observed in the PGL carrying the SLC25A11 mutation. Moreover, 5-hmC immunohistochemistry was negative in all but one SLC25A11-mutated tumor, whereas H3K9me3 and H3K27me3 stainings were positive in all cases [86].

A novel germline mutation in the DNA-methyltransferase 3 alpha (DNMT3A) gene was identified in a 23-year-old female patient with multiple PGL (larynx, carotid, jugulotympanic, juxtavagal, and mediastinum). De novo DNA methyltransferases, DNMT3A and DNMT3B, establish DNA methylation patterns during embryonic development. A second germline DNMT3A mutation was identified in a 54-year-old 
female with two head and neck PGL, of whom the mother also was diagnosed with bilateral head and neck PGL. DNMT3A-mutated PGL showed strong immunostaining of $\mathrm{H} 3 \mathrm{~K} 9 \mathrm{me} 3$ [87].

An overview of PCC/PGL susceptibility genes and tumor associations, including clues for diagnosis and immunohistochemical markers is depicted in > Table 1 .

\section{Conclusions}

PCC have been associated with a large number of genes that may be mutated in the germline or somatically. In this review, we have concentrated on genes that are associated with PCC (and not with PGL only) and on those that have been described at sufficient frequency of occurrence and/or for which data on the relationship between gross, microscopic and immunohistochemical details on the one hand and genetic background on the other hand were available.

It should be concluded that important clues can be gathered from the attentive study of adrenalectomy specimens and the corresponding microscopy. Specifically, the presence of bilateral disease and/or multiple nodules should raise suspicion for hereditary disease, most notably MEN2 syndrome. If tumors are particularly hemorrhagic and vascular, a diagnosis of VHL disease could be entertained. Composite histology between PCC and a neuroblastic tumor has most often been described in the context of NF1 gene abnormalities.

With regard to immunohistochemistry, the use of SDHA and SDHB immunohistochemistry should be regarded as standard for specialized centers, allowing to direct genetic testing to the group of SDH genes or away from it (if there is a normal pattern of SDHB immunostaining). Although much less frequent and therefore much less reported, immunohistochemistry for MAX and for 2-SC and 5-hmc in the context of $\mathrm{FH}$ mutations may have a place in a specialized setting.

It should be noted that with the advent of targeted sequencing using NGS panels, and even more when using whole exome or whole genome sequencing, all PCC (and PGL) susceptibility genes can be analyzed at the same time. Therefore, stepwise analysis on the basis of clinical or pathological clues will most likely become obsolete. However, immunohistochemistry will continue to have an important ancillary role in the analysis of genetic variants of unknown significance.

\section{Conflict of Interest}

The authors declare that they have no conflict of interest.

\section{References}

[1] Lloyd O, Kloppel R. WHO Classification of tumours of endocrine organs.Lyon: 2017 4th edition

[2] Lenders JW, Duh QY, Eisenhofer G, Gimenez-Roqueplo AP, Grebe SK, Murad MH, Naruse M, Pacak K, Young WF Jr. Pheochromocytoma and paraganglioma: An endocrine society clinical practice guideline. J Clin Endocrinol Metab 2014; 99: 1915-1942

[3] Fishbein L, Nathanson KL. Pheochromocytoma and paraganglioma: Understanding the complexitis of the genetic background. Cancer Genet 2012; 205: 1-11
[4] Lyssikatos C, Faucs FR, Stratakis CA. Familial endocrine tumor syndromes. In: Mete O, Asa SL. (eds) Endocrine Pathology. Cambridge: 2016: $56-70$

[5] Wohllk N, Schweizer H, Erlic Z, Schmid KW, Walz MK, Raue F, Neumann HP. Multiple endocrine neoplasia type 2. Best Pract Res Clin Endocrinol Metab 2010; 24: 371-387

[6] Raue F, Frank-Raue K. Genotype-phenotype correlation in multiple endocrine neoplasia type 2. Clinics (Sao Paulo) 2012; 67: 69-75

[7] Modigliani E, Vasen HM, Raue K. Pheochromocytoma in multiple endocrine neoplasia type 2: European study: The Euromen Study Group. J Intern Med 1995; 238: 363-367

[8] Carney JA, Sizemore GW, Sheps SG. Adrenal medullary disease in multiple endocrine neoplasia, type 2: Pheochromocytoma and its precursors. Am J Clin Path 1967; 66: 279-290

[9] Korpershoek E, Petri B], Post E, van Eijck CH, Oldenburg RA, Belt E], de Herder WW, de Krijger RR, Dinjens WN. Adrenal Medullar Hyperplasia is a precursor lesion for pheochromocytoma in MEN2 syndrome. Neoplasia 2014; 16: 868-873

[10] Turchini J, Cheung VKY, Tischler AS, De Krijger RR, Gill AJ. Pathology and genetics of phaeochromocytoma and paraganglioma. Histopathology 2018; 72: 97-105

[11] Oudijk L, de Krijger RR, Pacak K, Tischler AS. Adrenal medulla and extra-adrenal paraganglia. In: Mete O, Asa SL. (eds) Endocrine Pathology. Cambridge: 2016: 628-676

[12] Maher ER, Neumann HP, Richard S. von Hippel-Lindau disease: A clinical and scientific review. Eur J Hum Genet 2011; 19: 617-623

[13] Koch CA, Mauro D, Walther MM, Linehan WM, Vortmeyer AO, Jaffe R, Pacak K, Chrousos GP, Zhuang Z, Lubensky IA. Phaeochromocytoma in von Hippel-Lindau disease: Distinct histopathological phenotype compared to pheochromocytoma in multiple endocrine neoplasia type 2. Endocr Pathol 2002; 13: 17-27

[14] Pinato DJ, Ramachandran R, Toussi ST, Vergine M, Ngo N, Sharma R, Lloyd T, Meeran K, Palazzo F, Martin N, Khoo B, Dina R, Tan TM. Immunohistochemical markers of the hypoxic response can identify malignancy in phaechromocytomas and paragangliomas and optimize the detection of tumours with VHL germline mutations. $\mathrm{Br}$ J Cancer 2013; 108: 429-437

[15] Ferner RE, Huson SM, Thomas N, Moss C, Willshaw H, Evans DG, Upadhyaya M, Towers R, Gleeson M, Steiger C, Kirby A. Guidelines for the diagnosis and management of individuals with neurofibromatosis 1. J Med Genet 2007; 44: 81-88

[16] Kimura N, Watanabe T, Fukase M, Wakita A, Noshiro T, Kimura I. Neurofibromin and NF1 gene analysis in composite pheochromocytoma and tumors associated with von Recklinghausen's disease. Mod Pathol 2002; 15: 183-188

[17] Stenman A, Svahn F, Welander J, Gustavson B, Söderkvist P, Gimm O, Juhlin CC. Immunohistochemical NF1 analysis does not predict NF1 gene mutation status in pheochromocytoma. Endocr Pathol 2015; 26: 9-14

[18] Gill AJ. Succinate dehydrogenase (SDH) and mitochondrial driven neoplasia. Pathology 2012; 44: 285-292

[19] Hao HX, Khalimonchuk O, Schraders M, Dephoure N, Bayley JP, Kunst H, Devilee P, Cremers CW, Schiffman JD, Bentz BG, Gygi SP, Winge DR, Kremer $\mathrm{H}$, Rutter J. SDH5, a gene required for flavination of succinate dehydrogenase, is mutated in paraganglioma. Science 2009; 325 (5944): 1139-1142

[20] van Nederveen FH, Gaal J, Favier ], Korpershoek E, Oldenburg RA, de Bruyn EM, Sleddens HF, Derkx P, Rivière J, Dannenberg H, Petri B], Komminoth P, Pacak K, Hop WC, Pollard PJ, Mannelli M, Bayley JP, Perren A, Niemann S, Verhofstad AA, de Bruïne AP, Maher ER, Tissier F, Méatchi T, Badoual C, Bertherat J, Amar L, Alataki D, Van Marck E, Ferrau F, François J, de Herder WW, Peeters MP, van Linge A, Lenders JW, Gimenez-Roqueplo AP, de Krijger RR, Dinjens WN. An immunohistochemical procedure to detect patients with paraganglioma and 
phaeochromocytoma with germline SDHB, SDHC, or SDHD gene mutations: a retrospective and prospective analysis. Lancet Oncol. 2009: 10: 764-771

[21] Currás-Freixes M, Inglada-Pérez L, Mancikova V, Montero-Conde C, Letón R, Comino-Méndez I, Apellániz-Ruiz M, Sánchez-Barroso L, Aguirre Sánchez-Covisa M, Alcázar V, Aller J, Álvarez-Escolá C, Andía-Melero VM, Azriel-Mira S, Calatayud-Gutiérrez M, Díaz JÁ, Díez-Hernández A, Lamas-Oliveira C, Marazuela M, Matias-Guiu X, Meoro-Avilés A, Patiño-García A, Pedrinaci S, Riesco-Eizaguirre G, Sábado-Álvarez C, Sáez-Villaverde R, Sainz de Los Terreros A, Sanz Guadarrama Ó, Sastre-Marcos J, Scolá-Yurrita B, Segura-Huerta Á, Serrano-Corredor Mde L, Villar-Vicente MR, Rodríguez-Antona C, Korpershoek E, Cascón A, Robledo M. Recommendations for somatic and germline genetic testing of single pheochromocytoma and paraganglioma based on findings from a series of 329 patients. J Med Genet 2015; 52: 647-656

[22] Korpershoek E, Favier J, Gaal ], Burnichon N, van Gessel B, Oudijk L, Badoual C, Gadessaud N, Venisse A, Bayley JP, van Dooren MF, de Herder WW, Tissier F, Plouin PF, van Nederveen FH, Dinjens WN, Gimenez-Roqueplo AP, de Krijger RR. SDHA immunohistochemistry detects germline SDHA gene mutations in apparently sporadic paragangliomas and pheochromocytomas. J Clin Endocrinol Metab 2011; 96: E1472-E1476

[23] Menara M, Oudijk L, Badoual C, Bertherat ], Lepoutre-Lussey C, Amar L, Iturrioz X, Sibony M, Zinzindohoué F, de Krijger R, Gimenez-Roqueplo AP, Favier J. SDHD immunohistochemistry: A new tool to validate SDHx mutations in pheochromocytoma/paraganglioma. J Clin Endocrinol Metab 2015; 100: E287-E291

[24] Papathomas TG, Oudijk L, Persu A, Gill AJ, van Nederveen F, Tischler AS, Tissier F, Volante M, Matias-Guiu X, Smid M, Favier J, Rapizzi E, Libe R, Currás-Freixes M, Aydin S, Huynh T, Lichtenauer U, van Berkel A, Canu L, Domingues R, Clifton-Bligh RJ, Bialas M, Vikkula M, Baretton G, Papotti M, Nesi G, Badoual C, Pacak K, Eisenhofer G, Timmers HJ, Beuschlein F, Bertherat J, Mannelli M, Robledo M, Gimenez-Roqueplo AP, Dinjens WN, Korpershoek E, de Krijger RR. SDHB/SDHA immunohistochemistry in pheochromocytomas and paragangliomas: a multicenter interobserver variation analysis using virtual microscopy: a Multinational Study of the European Network for the Study of Adrenal Tumors (ENS@T). Mod Pathol 2015; 28: 807-821

[25] Gill AJ. Succinate dehydrogenase (SDH)-deficient neoplasia. Histopathology 2018; 72: 106-116

[26] Gimenez-Roqueplo AP, Favier ], Rustin P, Rieubland C, Crespin M, Nau V, Khau Van Kien P, Corvol P, Plouin PF, Jeunemaitre X. Mutations in the SDHB gene are associated with extra-adrenal and/or malignant phaeochromocytomas. Cancer Res 2003; 63: 5615-5621

[27] Andrews KA, Ascher DB, Pires DEV, Barnes DR, Vialard L, Casey RT, Bradshaw N, Adlard J, Aylwin S, Brennan P, Brewer C, Cole T, Cook JA, Davidson R, Donaldson A, Fryer A, Greenhalgh L, Hodgson SV, Irving R, Lalloo F, McConachie M, McConnell VPM, Morrison PJ, Murday V, Park SM, Simpson HL, Snape K, Stewart S, Tomkins SE, Wallis Y, Izatt L, Goudie D, Lindsay RS, Perry CG, Woodward ER, Antoniou AC, Maher ER. Tumour risks and genotype-phenotype correlations associated with germline variants in succinate dehydrogenase subunit genes SDHB, SDHC and SDHD. J Med Genet 2018; 55: 384-394

[28] King KS, Prodanov T, Kantorovich V, Fojo T, Hewitt JK, Zacharin M, Wesley R, Lodish M, Raygada M, Gimenez-Roqueplo AP, McCormack S, Eisenhofer G, Milosevic D, Kebebew E, Stratakis CA, Pacak K. Metastatic pheochromocytoma/paraganglioma related to primary tumor development in childhood or adolescence: significant link to SDHB mutations. J Clin Oncol 2011; 29: 4137-4142

[29] Hensen EF, Siemers MD, Jansen JC, Corssmit EP, Romijn JA, Tops CM, van der Mey AG, Devilee P, Cornelisse C], Bayley JP, Vriends AH. Mutations in SDHD are the major determinants of the clinical characteristics of Dutch head and neck paraganglioma patients. Clin Endocrinol (Oxf) 2011; 75: 650-655
[30] van der Mey AG, Maaswinkel-Mooy PD, Cornelisse C], Schmidt PH, van de Kamp J]. Genomic imprinting in hereditary glomus tumours: Evidence for new genetic theory. Lancet 1989; 2 (8675): 1291-1294

[31] van der Tuin K, Mensenkamp AR, Tops CM], Corssmit EPM, Dinjens WN, van de Horst-Schrivers AN, Jansen JC, de Jong MM, Kunst HPM, Kusters B, Leter EM, Morreau H, van Nesselrooij BMP, Oldenburg RA, Spruijt L, Hes FJ, Timmers HJLM. Clinical Aspects of SDHA-Related Pheochromocytoma and Paraganglioma: A Nationwide Study. J Clin Endocrinol Metab 2018; 103: 438-445

[32] Gill AJ, Chou A, Vilain R, Clarkson A, Lui M, Jin R, Tobias V, Samra ], Goldstein D, Smith C, Sioson L, Parker N, Smith RC, Sywak M, Sidhu SB, Wyatt JM, Robinson BG, Eckstein RP, Benn DE, Clifton-Bligh RJ. Immunohistochemistry for SDHB divides gastrointestinal stromal tumors (GISTs) into 2 distinct types. Am J Surg Pathol 2010; 34: 636-644

[33] Gaal J, Stratakis CA, Carney JA, Ball ER, Korpershoek E, Lodish MB, Levy I, Xekouki P, van Nederveen FH, den Bakker MA, O'Sullivan M, Dinjens WN, de Krijger RR. SDHB immunohistochemistry: a useful tool in the diagnosis of Carney-Stratakis and Carney triad gastrointestinal stromal tumors. Mod Pathol 2011; 24: 147-151

[34] Oudijk L, Gaal J, Korpershoek E, van Nederveen FH, Kelly L, Schiavon G, Verweij J, Mathijssen RH, den Bakker MA, Oldenburg RA, van Loon RL, O'Sullivan MJ, de Krijger RR, Dinjens WN. SDHA mutations in adult and pediatric wild-type gastrointestinal stromal tumors. Mod Pathol 2013; 26: 456-463

[35] Pasini B, McWhinney SR, Bei T, Matyakhina L, Stergiopoulos S, Muchow M, Boikos SA, Ferrando B, Pacak K, Assie G, Baudin E, Chompret A, Ellison JW, Briere JJ, Rustin P, Gimenez-Roqueplo AP, Eng C, Carney JA, Stratakis CA. Clinical and molecular genetics of patients with the Carney-Stratakis syndrome and germline mutations of the genes coding for the succinate dehydrogenase subunits SDHB, SDHC, and SDHD. Eur J Hum Genet 2008; 16: 79-88

[36] Stratakis CA, Carney JA. The triad of paragangliomas, gastric stromal tumours and pulmonary chondromas (Carney triad), and the dyad of paragangliomas and gastric stromal sarcomas (Carney-Stratakis syndrome): molecular genetics and clinical implications. J Intern Med 2009; 266: 43-52

[37] Haller F, Moskalev EA, Faucz FR, Barthelmess S, Wiemann S, Bieg M, Assie G, Bertherat J, Schaefer IM, Otto C, Rattenberry E, Maher ER, Ströbel P, Werner M, Carney JA, Hartmann A, Stratakis CA, Agaimy A. Aberrant DNA hypermethylation of SDHC: A novel mechanism of tumor development in Carney triad. Endocr Relat Cancer 2014; 21: 567-577

[38] Kuroda N, Yorita K, Nagasaki M, Harada Y, Ohe C, Jeruc ], Raspollini MR, Michal M, Hes O, Amin MB. Review of succinate dehydrogenase-deficient renal cell carcinoma with focus on clinical and pathobiological aspects. Pol J Pathol 2016; 67: 3-7

[39] Gill AJ, Lipton L, Taylor ], Benn DE, Richardson AL, Frydenberg M, Shapiro J, Clifton-Bligh RJ, Chow CW, Bogwitz M. Germline SDHC mutation presenting as recurrent SDH deficient GIST and renal carcinoma. Pathology 2013; 45: 689-691

[40] Yakirevich E, Ali SM, Mega A, McMahon C, Brodsky AS, Ross JS, Allen ], Elvin JA, Safran H, Resnick MB. A Novel SDHA-deficient Renal Cell Carcinoma Revealed by Comprehensive Genomic Profiling. Am J Surg Pathol 2015; 39: 858-863

[41] Niemeijer ND, Papathomas TG, Korpershoek E, de Krijger RR, Oudijk L, Morreau H, Bayley JP, Hes FJ, Jansen JC, Dinjens WN, Corssmit EP. Succinate Dehydrogenase (SDH)-Deficient Pancreatic Neuroendocrine Tumor Expands the SDH-Related Tumor Spectrum. J Clin Endocrinol Metab 2015; 100: E1386-E1393

[42] Comino-Méndez I, Gracia-Aznárez FJ, Schiavi F, Landa I, Leandro-García LJ, Letón R, Honrado E, Ramos-Medina R, Caronia D, Pita G, GómezGraña A, de Cubas AA, Inglada-Pérez L, Maliszewska A, Taschin E, Bobisse S, Pica G, Loli P, Hernández-Lavado R, Díaz JA, Gómez-Morales M, González-Neira A, Roncador G, Rodríguez-Antona C, Benítez J, Mannelli M, Opocher G, Robledo M, Cascón A. Exome sequencing identifies MAX mutations as a cause of hereditary PCC. Nat Genet 2011; 43: 663-667 
[43] Burnichon N, Cascón A, Schiavi F, Morales NP, Comino-Méndez I, Abermil N, Inglada-Pérez L, de Cubas AA, Amar L, Barontini M, de Quirós SB, Bertherat J, Bignon YJ, Blok MJ, Bobisse S, Borrego S, Castellano $\mathrm{M}$, Chanson $\mathrm{P}$, Chiara MD, Corssmit EP, Giacchè $\mathrm{M}$, de Krijger RR, Ercolino T, Girerd X, Gómez-García EB, Gómez-Graña A Guilhem I, Hes F], Honrado E, Korpershoek E, Lenders JW, Letón R, Mensenkamp AR, Merlo A, Mori L, Murat A, Pierre P, Plouin PF, Prodanov T, Quesada-Charneco M, Qin N, Rapizzi E, Raymond V, Reisch N, Roncador G, Ruiz-Ferrer M, Schillo F, Stegmann AP, Suarez C, Taschin E, Timmers HJ, Tops CM, Urioste M, Beuschlein F, Pacak K, Mannelli M, Dahia PL, Opocher G, Eisenhofer G, Gimenez-Roqueplo AP, Robledo M. MAX mutations cause hereditary and sporadic PCC and paraganglioma. Clin Cancer Res 2012; 18: 2828-2837

[44] Korpershoek E, Koffy D, Eussen BH, Oudijk L, Papathomas TG, van Nederveen FH, Belt E], Franssen G], Restuccia DF, Krol NM, van der Luijt RB, Feelders RA, Oldenburg RA, van ljcken WF, de Klein A, de Herder WW, de Krijger RR, Dinjens WN. Complex MAX Rearrangement in a Family With Malignant PCC, Renal Oncocytoma, and Erythrocytosis. J ClinEndocrinol Metab 2016; 101: 453-460

[45] Cheung VKY, Gill AJ, Chou A. Old, New, and Emerging Immunohistochemical Markers in Pheochromocytoma and Paraganglioma. Endocr Pathol. 2018; 29: 169-175

[46] Tomlinson IP, Alam NA, Rowan AJ, Barclay E, Jaeger EE, Kelsell D, Leigh I, Gorman P, Lamlum H, Rahman S, Roylance RR, Olpin S, Bevan S, Barker K, Hearle N, Houlston RS, Kiuru M, Lehtonen R, Karhu A, Vilkki S, Laiho P, Eklund C, Vierimaa O, Aittomäki K, Hietala M, Sistonen P, Paetau A, Salovaara R, Herva R, Launonen V, Aaltonen LA. Multiple Leiomyoma Consortium. Germline mutations in $\mathrm{FH}$ predispose to dominantly inherited uterine fibroids, skin leiomyomata and papillary renal cell cancer. Nat Genet 2002; 30: 406-410

[47] Letouzé E, Martinelli C, Loriot C, Burnichon N, Abermil N, Ottolenghi C, Janin M, Menara M, Nguyen AT, Benit P, Buffet A, Marcaillou C, Bertherat J, Amar L, Rustin P, De Reyniès A, Gimenez-Roqueplo AP, Favier J. SDH mutations establish a hypermethylator phenotype in paraganglioma. Cancer Cell 2013; 23: 739-752

[48] Castro-Vega L], Buffet A, De Cubas AA, Cascón A, Menara M, Khalifa E, Amar L, Azriel S, Bourdeau I, Chabre O, Currás-Freixes M, Franco-Vidal V, Guillaud-Bataille M, Simian C, Morin A, Letón R, Gómez-Graña A, Pollard PJ, Rustin P, Robledo M, Favier J, Gimenez-Roqueplo AP. Germline mutations in FH confer predisposition to malignant PCC and PGL. Hum Mol Genet 2014; 23: 2440-2446

[49] Clark GR, Sciacovelli M, Gaude E, Walsh DM, Kirby G, Simpson MA, Trembath RC, Berg JN, Woodward ER, Kinning E, Morrison PJ, Frezza C, Maher ER, Germline FH. mutations presenting with pheochromocytoma. J Clin Endocrinol Metab 2014; 99: E2046-E2050

[50] Hoekstra AS, de Graaff MA, Briaire-de Bruijn IH, Ras C, Seifar RM, van Minderhout I, Cornelisse C], Hogendoorn PC, Breuning MH, Suijker ], Korpershoek E, Kunst HP, Frizzell N, Devilee P, Bayley JP, Bovée JV. Inactivation of SDH and $\mathrm{FH}$ cause loss of $5 \mathrm{hmC}$ and increased $\mathrm{H} 3 \mathrm{~K} 9 \mathrm{me} 3$ in paraganglioma/pheochromocytoma and smooth muscle tumors. Oncotarget 2015; 6: 38777-38788

[51] Qin Y, Yao L, King EE, Buddavarapu K, Lenci RE, Chocron ES, Lechleiter JD, Sass M, Aronin N, Schiavi F, Boaretto F, Opocher G, Toledo RA, Toledo SP, Stiles C, Aguiar RC, Dahia PL. Germline mutations in TMEM127 confer susceptibility to PCC. Nat Genet 2010; 42: 229-233

[52] Neumann HP, Sullivan M, Winter A, Malinoc A, Hoffmann MM, Boedeker CC, Bertz H, Walz MK, Moeller LC, Schmid KW, Eng C. Germline mutations of the TMEM127 gene in patients with paraganglioma of head and neck and extraadrenal abdominal sites. J Clin Endocrinol Metab 2011; 96: E1279-E1282

[53] Yao L, Schiavi F, Cascon A, Qin Y, Inglada-Pérez L, King EE, Toledo RA, Ercolino T, Rapizzi E, Ricketts C], Mori L, Giacchè M, Mendola A, Taschin E, Boaretto F, Loli P, lacobone M, Rossi GP, Biondi B, Lima-Junior JV, Kater CE, Bex M, Vikkula M, Grossman AB, Gruber SB, Barontini M, Persu A, Castellano M, Toledo SP, Maher ER, Mannelli M, Opocher G, Robledo M,
Dahia PL. Spectrum and prevalence of FP/TMEM127 gene mutations in pheochromocytomas and paragangliomas. JAMA 2010; 304: 2611-2619

[54] Ladroue C, Carcenac R, Leporrier M, Gad S, Le Hello C, Galateau-Salle F, Feunteun J, Pouyssegur J, Richard S, Gardie B. PHD2 mutation and congenital erythrocytosis with paraganglioma. N Engl J Med 2008; 359: 2685-2692

[55] Yang C, Zhuang Z, Fliedner SM, Shankavaram U, Sun MG, Bullova P, Zhu R, Elkahloun AG, Kourlas PJ, Merino M, Kebebew E, Pacak K. Germ-line PHD1 and PHD2 mutations detected in patients with pheochromocytoma/paraganglioma-polycythemia. J Mol Med (Berl) 2015; 93: 93-104

[56] Kaelin WG Jr., Ratcliffe PJ. Oxygen sensing by metazoans: The central role of the HIF hydroxylase pathway. Mol Cell 2008; 30: 393-402

[57] Zhuang Z, Yang C, Lorenzo F, Merino M, Fojo T, Kebebew E, Popovic V, Stratakis CA, Prchal JT, Pacak K. Somatic HIF2A gain-of-function mutations in paraganglioma with polycythemia. N Engl J Med 2012; 367: 922-930

[58] Favier ], Buffet A, Gimenez-Roqueplo AP. HIF2A mutations in paraganglioma with polycythemia. N Engl J Med 2012; 367: 2161

[59] Pacak K, Jochmanova I, Prodanov T, Yang C, Merino M], Fojo T, Prchal JT, Tischler AS, Lechan RM, Zhuang Z. New syndrome of paraganglioma and somatostatinoma associated with polycythemia. J Clin Oncol 2013; 31: 1690-1698

[60] Lorenzo FR, Yang C, Ng Tang Fui M, Vankayalapati H, Zhuang Z, Huynh T, Grossmann M, Pacak K, Prchal JT. A novel EPAS1/HIF2A germline mutation in a congenital polycythemia with paraganglioma. J Mol Med (Berl) 2013; 91: 507-512

[61] Welander ], Andreasson A, Brauckhoff M, Bäckdahl M, Larsson C, Gimm O, Söderkvist P. Frequent EPAS1/HIF2 $\alpha$ exons 9 and 12 mutations in non-familial pheochromocytoma. Endocr Relat Cancer 2014; 21: 495-504

[62] Percy M], Furlow PW, Lucas GS, Li X, Lappin TR, McMullin MF, Lee FS. A gain-of-function mutation in the HIF2A gene in familial erythrocytosis. N Engl J Med 2008; 358: 162-168

[63] Taïeb D, Yang C, Delenne B, Zhuang Z, Barlier A, Sebag F, Pacak K. First report of bilateral pheochromocytoma in the clinical spectrum of HIF2A-related polycythemia-paraganglioma syndrome. J Clin Endocrinol Metab 2013; 98: E908-E913

[64] Comino-Méndez I, de Cubas AA, Bernal C, Álvarez-Escolá C, Sánchez-Malo C, Ramírez-Tortosa CL, Pedrinaci S, Rapizzi E, Ercolino T, Bernini G, Bacca A, Letón R, Pita G, Alonso MR, Leandro-García LJ, Gómez-Graña A, Inglada-Pérez L, Mancikova V, Rodríguez-Antona C, Mannelli M, Robledo M, Cascón A. Tumoral EPAS1 (HIF2A) mutations explain sporadic pheochromocytoma and paraganglioma in the absence of erythrocytosis. Hum Mol Genet 2013; 22: 2169-2176

[65] Toledo RA, Qin Y, Srikantan S, Morales NP, Li Q, Deng Y, Kim SW, Pereira MA, Toledo SP, Su X, Aguiar RC, Dahia PL. In vivo and in vitro oncogenic effects of HIF2A mutations in pheochromocytomas and paragangliomas. Endocr Relat Cancer 2013; 20: 349-359

[66] Buffet A, Smati S, Mansuy L, Ménara M, Lebras M, Heymann MF, Simian C, Favier J, Murat A, Cariou B, Gimenez-Roqueplo AP. Mosaicism in HIF2A-related polycythemia-paraganglioma syndrome. J Clin Endocrinol Metab 2014; 99: E369-E373

[67] Nangaku M, Sato-Yoshitake R, Okada Y, Noda Y, Takemura R, Yamazaki H, Hirokawa N. KIF1B, a novel microtubule plus end-directed monomeric motor protein for transport of mitochondria. Cell 1994; 79: 1209-1220

[68] Nagai M, Ichimiya S, Ozaki T, Seki N, Mihara M, Furuta S, Ohira M, Tomioka N, Nomura N, Sakiyama S, Kubo O, Takakura K, Hori T, Nakagawara A. Identification of the full-length KIAA0591 gene encoding a novel kinesin-related protein which is mapped to the neuroblastoma suppressor gene locus at 1p36.2. Int J Oncol 2000; 16 : 907-916

[69] Zhao C, Takita J, Tanaka Y, Setou M, Nakagawa T, Takeda S, Yang HW, Terada S, Nakata T, Takei Y, Saito M, Tsuji S, Hayashi Y, Hirokawa N. Charcot-Marie-Tooth disease type 2A caused by mutation in a microtubule motor KIF1Bbeta. Cell 2001; 105: 587-597 
[70] Schlisio S, Kenchappa RS, Vredeveld LC, George RE, Stewart R, Greulich H, Shahriari K, Nguyen NV, Pigny P, Dahia PL, Pomeroy SL, Maris JM, Look AT, Meyerson M, Peeper DS, Carter BD, Kaelin WG Jr.. The kinesin KIF1Bbeta acts downstream from EgIN3 to induce apoptosis and is a potential 1p36 tumor suppressor. Genes Dev 2008; 22: 884-893

[71] Evenepoel L, Helaers R, Vroonen L, Aydin S, Hamoir M, Maiter D, Vikkula M, Persu A. KIF1B and NF1 are the most frequently mutated genes in paraganglioma and pheochromocytoma tumors. Endocr Relat Cancer 2017; 24: L57-L61

[72] Yeh IT, Lenci RE, Qin Y, Buddavarapu K, Ligon AH, Leteurtre E, Do Cao C, Cardot-Bauters C, Pigny P, Dahia PL. A germline mutation of the KIF1B beta gene on $1 \mathrm{p} 36$ in a family with neural and nonneural tumors. Hum Genet 2008; 124: 279-285

[73] Agarwal SK, Guru SC, Heppner C, Erdos MR, Collins RM, Park SY, Saggar S, Chandrasekharappa SC, Collins FS, Spiegel AM, Marx SJ, Burns AL. Menin interacts with the AP1 transcription factor JunD and represses JunD-activated transcription. Cell 1999; 96: 143-152

[74] Gatta-Cherifi B, Chabre O, Murat A, Niccoli P, Cardot-Bauters C, Rohmer V, Young J, Delemer B, Du Boullay H, Verger MF, Kuhn JM, Sadoul JL, Ruszniewski P, Beckers A, Monsaingeon M, Baudin E, Goudet P, Tabarin A. Adrenal involvement in MEN1. Analysis of 715 cases from the Groupe d'etude des Tumeurs Endocrines database. Eur J Endocrinol 2012; 166: 269-279

[75] Schussheim DH, Skarulis MC, Agarwal SK, Simonds WF, Burns AL, Spiegel AM, Marx SJ. Multiple endocrine neoplasia type 1: New clinical and basic findings. Trends Endocrinol Metab 2001; 12: 173-178

[76] Carty SE, Helm AK, Amico JA, Clarke MR, Foley TP, Watson CG, Mulvihill JJ. The variable penetrance and spectrum of manifestations of multiple endocrine neoplasia type 1 . Surgery 1998; 124: 1106-1113 discussion 1113-1114

[77] Okada R, Shimura T, Tsukida S, Ando ], Kofunato Y, Momma T, Yashima R, Koyama Y, Suzuki S, Takenoshita S. Concomitant existence of pheochromocytoma in a patient with multiple endocrine neoplasia type 1. Surg Case Rep 2016; 2: 84

[78] Xekouki P, Stratakis CA. Succinate dehydrogenase (SDHx) mutations in pituitary tumors: Could this be a new role for mitochondrial complex II and/or Krebs cycle defects? Endocr Relat Cancer 2012; 19: C33-C40

[79] O’Toole SM, Dénes ], Robledo M, Stratakis CA, Korbonits M. 15 Years of Paraganglioma: The association of pituitary adenomas and phaeochromocytomas or paragangliomas. Endocr Relat Cancer 2015; 22: T105-T122

[80] Dénes ], Swords F, Rattenberry E, Stals K, Owens M, Cranston T, Xekouki P, Moran L, Kumar A, Wassif C, Fersht N, Baldeweg SE, Morris D, Lightman S, Agha A, Rees A, Grieve J, Powell M, Boguszewski CL, Dutta P, Thakker RV, Srirangalingam U, Thompson CJ, Druce M, Higham C, Davis J, Eeles R, Stevenson M, O'Sullivan B, Taniere P, Skordilis K, Gabrovska P, Barlier A, Webb SM, Aulinas A, Drake WM, Bevan JS, Preda C, Dalantaeva N, Ribeiro-Oliveira A Jr., Garcia IT, Yordanova G, lotova V, Evanson J, Grossman AB, Trouillas J, Ellard S, Stratakis CA, Maher ER, Roncaroli F, Korbonits $\mathrm{M}$. Heterogeneous genetic background of the association of pheochromocytoma/paraganglioma and pituitary adenoma: results from a large patient cohort. J Clin Endocrinol Metab 2015; 100: E531-E541
[81] Huang SC, Zhuang Z, Weil RJ, Pack S, Wang C, Krutzsch HC, Pham TA, Lubensky IA. Nuclear/cytoplasmic localization of the multiple endocrine neoplasia type 1 gene product, menin. Lab Invest 1999; 79: 301-310

[82] Grolmusz VK, Borka K, Kövesdi A, Németh K, Balogh K, Dékány C, Kiss A, Szentpéteri A, Sármán B, Somogyi A, Csajbók É, Valkusz Z, Tóth M, Igaz P, Rácz K, Patócs A. MEN1 mutations and potentially MEN1-targeting miRNAs are responsible for menin deficiency in sporadic and MEN1 syndrome-associated primary hyperparathyroidism. Virchows Arch 2017; 471: 401-411

[83] Cascón A, Comino-Méndez I, Currás-Freixes M, de Cubas AA, Contreras L, Richter S, Peitzsch M, Mancikova V, Inglada-Pérez L, Pérez-Barrios A, Calatayud M, Azriel S, Villar-Vicente R, Aller J, Setién F, Moran S, Garcia JF, Río-Machín A, Letón R, Gómez-Graña Á, Apellániz-Ruiz M, Roncador G, Esteller M, Rodríguez-Antona C, Satrústegui J, Eisenhofer G, Urioste M, Robledo $\mathrm{M}$. Whole-exome sequencing identifies $\mathrm{MDH} 2$ as a new familial paraganglioma gene. J Natl Cancer Inst 2015; 107: pii: djv053 doi:10.1093/jnci/djv053

[84] Calsina B, Currás-Freixes M, Buffet A, Pons T, Contreras L, Letón R, Comino-Méndez I, Remacha L, Calatayud M, Obispo B, Martin A, Cohen R, Richter S, Balmaña J, Korpershoek E, Rapizzi E, Deutschbein T, Vroonen L, Favier J, de Krijger RR, Fassnacht M, Beuschlein F, Timmers HJ, Eisenhofer G, Mannelli M, Pacak K, Satrústegui J, Rodríguez-Antona C, Amar L, Cascón A, Dölker N, Gimenez-Roqueplo AP, Robledo M. Role of MDH2 pathogenic variant in pheochromocytoma and paraganglioma patients. Genet Med 2018, doi:10.1038/ s41436-018-0068-7

[85] Remacha L, Comino-Méndez I, Richter S, Contreras L, Currás-Freixes M, Pita G, Letón R, Galarreta A, Torres-Pérez R, Honrado E, Jiménez S, Maestre L, Moran S, Esteller M, Satrústegui ], Eisenhofer G, Robledo M, Cascón A. Targeted Exome Sequencing of Krebs Cycle Genes Reveals Candidate Cancer-Predisposing Mutations in Pheochromocytomas and Paragangliomas. Clin Cancer Res 2017; 23: 6315-6324

[86] Buffet A, Morin A, Castro-Vega LJ, Habarou F, Lussey-Lepoutre C, Letouzé E, Lefebvre H, Guilhem I, Haissaguerre M, Raingeard I, Padilla-Girola M, Tran T, Tchara L, Bertherat J, Amar L, Ottolenghi C, Burnichon N, Gimenez-Roqueplo AP, Favier J. Germline Mutations in the Mitochondrial 2-Oxoglutarate/Malate Carrier SLC25A11 Gene Confer a Predisposition to Metastatic Paragangliomas. Cancer Res 2018; 78: 1914-1922

[87] Remacha L, Currás-Freixes M, Torres-Ruiz R, Schiavi F, Torres-Pérez R, Calsina B, Letón R, Comino-Méndez I, Roldán-Romero JM, Montero-Conde C, Santos M, Pérez LI, Pita G, Alonso MR, Honrado E, Pedrinaci S, Crespo-Facorro B, Percesepe A, Falcioni M, Rodríguez-Perales S, Korpershoek E, Ramón-Maiques S, Opocher G, Rodríguez-Antona C, Robledo M, Cascón A. Gain-of-function mutations in DNMT3A in patients with paraganglioma. Genet Med 2018, doi:10.1038/ s41436-018-0003-y 